Claremont Colleges

Scholarship@ Claremont

CMC Faculty Publications and Research

CMC Faculty Scholarship

8-1-2005

\title{
Understanding the Rise and Transformation of Business Collective Action in India
}

Aseema Sinha

Claremont Mckenna College

\section{Recommended Citation}

Aseema Sinha. 2005. "Understanding the Rise and Transformation of Business Collective Action in India," Business and Politics, Vol. 7: Issue 2, August 2005.

This Article is brought to you for free and open access by the CMC Faculty Scholarship at Scholarship @ Claremont. It has been accepted for inclusion in CMC Faculty Publications and Research by an authorized administrator of Scholarship @ Claremont. For more information, please contact scholarship@cuc.claremont.edu. 


\title{
Business and Politics
}

\begin{tabular}{lll}
\hline Volume 7, Issue 2 & Article 2 \\
\hline
\end{tabular}

\section{Understanding the Rise and Transformation of Business Collective Action in India}

\author{
Aseema Sinha*
}

*University of Wisconsin-Madison, asinha@polisci.wisc.edu

Copyright (C) 2005 by the authors. All rights reserved. No part of this publication may be reproduced, stored in a retrieval system, or transmitted, in any form or by any means, electronic, mechanical, photocopying, recording, or otherwise, without the prior written permission of the publisher, bepress, which has been given certain exclusive rights by the author. Business and Politics is produced by The Berkeley Electronic Press (bepress). http://www.bepress.com/bap 


\title{
Understanding the Rise and Transformation of Business Collective Action in India*
}

\author{
Aseema Sinha
}

\begin{abstract}
Scholars of business associations have recently learned a great deal about how associations contribute to development, but much less about the origins of such developmental associations. This essay introduces and assesses a new political explanation for the origins of 'developmental associations.' Conventional wisdom holds that developmental associations must be able to rise above political and collusive pressures and establish autonomy from states. Yet, I argue that these associations' developmental capacities emerge as a result of active state support by key actors, and in response to challenges and threats posed by competitive business organizations. Developmental associations emerge and acquire their capacities as they confront internal threats from other associations, as well as utilize the opportunities presented by the national state and international channels. In this view, functional or organizational capacity is not enough, rather, developmental business associations, must exhibit political capacity - that is the ability to manage the political environment, and respond to the structure of opportunities and threats. This explanation views developmental business associations as political organizations seeking power as well as offers a historically sensitive analysis of transformation of business politics in reforming India.
\end{abstract}

KEYWORDS: Development, Collective Action, Business Associations, Globalization, Developmental Associations, India

${ }^{*}$ See Colophon section in the ms. 
In India, in 1992, an engineering association called Confederation of Engineering Industry transformed itself into an all-industry association and changed its name to Confederation of Indian Industry (CII). ${ }^{1}$ At that time, Federation of Indian Chambers of Commerce and Industry (FICCI) and Association of Chambers of Commerce (Assocham), two national associations, dominated India's business scene. While many regional and sectoral business associations represented the diversity of business in India, a delayed international opening and democratic continuity had cemented a well-connected, protectionist elite-FICCI. FICCI was especially powerful with strong connections to the ruling Congress Party and the bureaucratic apparatus (Kochanek 1974; 1985; $1986 ; 1987 ; 1996)$. Nevertheless, another association rose to challenge its dominance in the early 1990s. Within a decade, CII rose to become a nationally recognized association representing diverse sectors of Indian industry. In response, FICCI, until then the dominant business association, revived itself and became increasingly developmental in nature. ${ }^{2}$ Thus, currently, India has two dominant developmentally oriented associations-CII, and FICCI-which compete with each other but also pursue many developmental activities at both the central and provincial levels. ${ }^{3}$

How may we understand such a quick and successful transition from a sectorally based, somewhat, narrow concerns of an engineering association into a nationally recognized apex association? This transformation poses a puzzle to theories of business development in countries like India. In a situation of 'statist pluralism' as in India (Rudolph and Rudolph 1987, 255), where numerous groups vie for the state's attention, the emergence of a developmentally oriented business association is unexpected. ${ }^{4}$ Olson (1965), Bardhan (1984 [1998]) and Rudolph

\footnotetext{
${ }^{1}$ CII's historical antecedents lie in the engineering industry. In 1974, the Association of Indian Engineering Industry (AIEI) was formed as a result of a merger of two engineering associations. In 1986 AIEI was re-christened as Confederation of Engineering Industry (CEI) as it began to invite other associations to be members. In 1992, it expanded its scope to become an all-industry association, and renamed itself as Confederation of Indian Industry (CII).

${ }^{2}$ Following Doner and Schneider (2000, 263), I define developmental associations as associations that improve the functioning of markets and states. For example, a developmental association may work toward the provision of better infrastructure by the state, or help firms to improve their quality performance, or help them to secure export markets through trade fairs, market surveys etc. ${ }^{3}$ Assocham, a smaller organization, is less powerful and visible but also performs many developmental activities.

${ }^{4}$ The literature on business and labor and state relations has been organized around the idea of democratic or societal corporatism (in contrast to liberal pluralist capitalism) associated with northern European countries. Scholars writing on developing countries introduced some innovations in the concept by invoking the concept of state corporatism where the state itself organized corporate interests, found in many Latin countries (e.g. Mexico and Brazil). Yet, the concept of state corporatism failed to adequately capture non-corporatist countries like India where state domination co-existed with multiplicity and plurality of societal interests. This led
} 
and Rudolph's arguments (1987) would suggest that rent seeking distributional coalitions would be the norm in an established democracy like India. ${ }^{5}$ Second, this transformation in business collective action in the early 1990s coincided with a comprehensive liberalization program wherein the role for collective action seemed accentuated. What governance role could a business association perform in the face of the apparent withdrawal of the state from regulatory activity? Liberalization seemed to reduce the role for political lobbying; yet, an organization that developed new tools of political access and influence rose to prominence. Furthermore, the transformation of an engineering association into an all industry association posed immense collective action dilemmas and obstacles for the association-FICCI, the competitor organization, enjoyed access to the then formal mechanisms of power, the membership base of CEI was not supportive of such a move, and a consultant had recommended against such a transformation. Moreover, competition between associations could weaken both associations. Yet in India, an engineering association transformed itself into an all industry confederation and its competitor acquired many developmental features. ${ }^{6}$ While competition between associations in India has led to fragmentation of business representation, it has also stimulated many developmental activities by the associations.

This sudden transformation in business politics in India also raises a larger theoretical puzzle about business collective action. When and how does business collective action emerge and succeed in developing country contexts? We know that common interests may not mobilize easily in defense of those interests (Olson 1965; Hardin 1982; Oliver 1993), yet systematic empirical and theoretical attention to the political context and institutional mechanisms that enable or hinder the formation and consolidation of common or collective interests remains scanty. We need better answers to the question: How does business-an integral segment of society-emerge to solve its collective action dilemma in dirigiste contexts and adjust in a rapidly changing and internationally complex world? One reason for this lacunae in the literature is that despite its power, business often finds it difficult to mobilize collectively to achieve broader developmental goals, especially in developing and large country contexts. ${ }^{7}$ In most developing

Rudolph and Rudolph $(1987,252-258)$ to propose a new concept: involuted pluralism or state dominated pluralism to refer to India.

${ }^{5}$ Also see Kochanek (1974); Herring (1999).

${ }^{6}$ The dependant variable of interest in this article is the transformation of a sectoral association into a multi-sectoral association and subsequent resurgence of a traditional association with many developmental features.

${ }^{7}$ See Smith (2000) for the argument that business in the US comes together only rarely. Also see, Hart (2004) and Vogel (1989). Offe and Wiesenthal (1985), in contrast, suggest that business collective action is easier than labor mobilization. For a comparative approach to the study of business-state relations see Wilson (2003). For studies of business-state interaction in other dirigiste contexts see, Payne (1994); Maxfield and Schneider (1997); Schneider (1998); and 
countries, states are more powerful and capital scarce and dependent upon government initiatives. State dirigisme and weak business development creates the conditions for rent-seeking relations between state actors and business groups, precluding positive and developmental relations between the two. ${ }^{8}$ Business associations, among the various 'weapons' of political mobilization wielded by business, promise an answer to the collective action dilemma posed above. ${ }^{9}$ In line with this realization, analytical and empirical attention has recently focused on the relationship between business associations and economic performance. Some argue that business associations are intrinsically rent seeking and distributive. $^{10}$ Others assess the impact of voluntary associations on economic performance, macroeconomic stabilization, and democratic consolidation in a more balanced manner. ${ }^{11}$ Recent reinterpretation of the East Asian miracle has sought to re-evaluate the role played by business associations and collective business groups. ${ }^{12}$ This body of work led scholars to challenge and go beyond the erstwhile "negative presumptions against 'special interests' in Mancur Olson's theories of collective action and their extensions in the NIE" (Doner and Schneider 2000, 262; Maxfield and Schneider 1997) to highlight the "positive" contributions of business associations. Such approaches highlight how business associations may respond to the functional needs of a system in crisis, and may perform "market-supporting or market-complementing activities" responding to crucial market and state failures pervasive in many developing and transitional economies.

Yet, these approaches are mostly concerned with the impact of business associations on economic development and leave unaddressed a prior question: Where do developmental associations come from? That is, what are the political (as opposed to efficiency-based) dynamics of the genesis and reproduction of developmental business associations? Neo-institutionalist approaches to the study of collective action, more generally, link material interests to action to effects, but are unable to grasp how new patterns of collective action arise or are

\footnotetext{
Kingstone (1999).

${ }^{8}$ Krueger (1974); Herring (1999); Evans (1995); and Kochanek (1974). South Korea and Japan are exceptions to this general pattern: In South Korea, for example, business and state came together to craft a developmental state [Fields (1997); Kang (2002); Noble (1998); and Chibber (2003)]. The contrast of South Korea with India is especially instructive. Chibber (2003) compares early business development in India and South Korea and argues that in early independent India (1940s and 1950s), the business class launched an offensive against developmental goals of the new Indian state, thus aborting a mutually beneficial relationship; this contributed to a failed developmental state in India.

${ }^{9}$ I define business associations as voluntary membership-driven organizations of business people, firms, or other associations.

${ }^{10}$ Olson (1965).

${ }^{11}$ Swensen (2002); Schmitter (1994); Perez-Aleman (2003); and Goldsmith (2002).

${ }^{12}$ Kim (1993); Kang (2002); and Evans (1995).
} 
transformed. An answer to this question would lead us to a more careful analysis of the political context of business development across diverse contexts. In a recent assessment, Ben Ross Schneider undertakes such a comparative analysis arguing that varying patterns of business organization may be traced to the actions of state officials (2004). ${ }^{13}$ This emphasis on the role of the state is a crucial corrective to the existing focus on functional attributes of associations. Building on his insight, I pay attention to openings in the "political opportunity structure," which allows us to better understand the role of state actors and other micropolitical institutions in encouraging or disorganizing business. ${ }^{14}$ These insights allow a more political analysis of how business strategies (developmental or otherwise) are themselves molded by the features of the political-institutional environment.

This paper examines change and transformation in the nature of interest group mobilization and state-business interaction in reforming India. ${ }^{15}$ This examination of a dynamic process allows me to put forward an alternative framework to the study of interest groups and business associations, one that is more attentive to the political origins of business power and to contextual institutional variables rather than mere organizational dynamics. In strong confirmation of the arguments presented by Schneider (2004), I find that state actors and intra-state dynamics play an unexpectedly large role in shaping business development in India even under conditions of neoliberal reform. A further explication of the conditions under which state actors facilitate business collective action (when and how) urges me to incorporate a key concept from the social movement literature - the political opportunity structure. I argue that it is openings within the state, intra-state conflicts, and weakness of existing business organizations that may lead certain state actors to encourage other business groups. Thus, I argue that the rise and reproduction of developmental associations is shaped by state actors and strengthens the political settlement that underlies their continued activism in politics. Most crucially, certain critical features of the political and business context, most notably competition with rival associations and the federal structure, shape the transformation of business associations and their specific organizational form. ${ }^{16}$

\footnotetext{
${ }^{13}$ Also see Doner and Schneider (2000) section on "external enforcement and economic performance" (pages 275-278) where they analyze briefly how discipline by states may make some associations more efficient.

${ }^{14}$ This concept is drawn from the social movement literature. For an introduction to the concept, see Tarrow (1998).

${ }^{15}$ In India, an economic reform program was launched in 1985 followed by comprehensive external and domestic liberalization in 1991.

${ }^{16}$ The concept of the political opportunity structure is more general and allows us to compare, for example, the limited role of the state in shaping business development countries like England versus their more activist role in Germany. It also could shed light on the disorganization of both
} 
This emphasis on the political and institutional context must not neglect to analyze the responses and strategies of the business associations themselves, which are purposive entities, seeking power for their organizations. Therefore, I argue that developmental business associations must have political capacity, i.e. the capacity to strategically respond to the specific external characteristics of the political system in addition to organizational and functional capacity. ${ }^{17}$ If this is so, then the pre-existing and historical institutional framework will profoundly shape the nature of business power and business activism, thereby challenging the functionalist expectation that globalization pressures are sufficient to transform fragmented business organizations into encompassing ones. In contrast, the incentives, actions, and behaviors of state actors mediate and refract functionalist imperatives.

In contrast to the approach adopted here, pluralist and neo-institutional perspectives are non-political and functional: Pluralist theories see the process of business transformation in non-partisan ways, while neo-institutional accounts see associations responding to market failures and state failures in adequate ways. ${ }^{18}$ My analysis goes against both pluralist and functionalist accounts of business associations by articulating a more realistic analysis of the political origins of associational transformation. In both the neo-institutionalists and pluralists arguments, business associations are mechanisms through which others-business actors - act; they are not purposive entities or political actors themselves. In contrast, the evidence presented in this paper shows that it is important to bring politics back into an analysis of business associations and unite historical and institutional approaches to the study of collective action by 'strong' actors. ${ }^{19}$ Such an approach would look at how collective action of business is transformed over time but without ignoring the role of institutions and political contextual variables in shaping that transformation. These questions have profound consequences for our understanding of business collective organization across other systems. While comparative political economy debates have identified different models of stateinterest group interaction (see Table 1 below) under situations where states are autonomous and when they are weak, these cross-sectional models do not generate unequivocal conclusions about the origins or transformations of these patterns of interest group development from one model to another.

\footnotetext{
labor and business in the US. For an analysis of the larger political context of business development in the US, see Gordon (1998); Lehne (2001); and Martin (2000).

${ }^{17}$ I elaborate the strategic responses by business associations in another article, "Business Strategies in Globalizing India: Reproduction and Transformation of Interest Representation in India."

${ }^{18} \mathrm{~A}$ classic statement of the pluralist argument is Truman (1971).

${ }^{19}$ Following Thelen's call to unite institutional and historical approaches in comparative political economy (Thelen 2002).
} 
Table 1: Comparative Models of State-Business Relations ${ }^{20}$

\begin{tabular}{|l|l|l|}
\hline $\begin{array}{l}\text { State } \Rightarrow \\
\text { Business } \\
\text { Coherent/Encompassing }\end{array}$ & $\begin{array}{l}\text { Autonomous } \\
\text { Corporatism Embedded Autonomy } \\
\text { Or Eermany } \\
\text { South Korea } \\
\text { Mexico } \\
\text { Chile }\end{array}$ & Liberal Pluralism \\
\hline Dispersed/Fragmented & $\begin{array}{l}\text { State Pluralism Or Embedded } \\
\text { Particularism, Or } \\
\text { Over-Developed State }\end{array}$ & $\begin{array}{l}\text { Pluralist State and Disorganized } \\
\text { Business }\end{array}$ \\
& $\begin{array}{l}\text { India, Brazil } \\
\text { United States } \\
\text { India }\end{array}$ \\
\hline
\end{tabular}

I organize the paper in four parts. First, I lay out the empirical puzzle of transformation and emergence of a business association in India. In section two, I examine how openings in the political opportunity structure, represented by prime minister Rajiv Gandhi's initiatives, facilitated the rise of CII. Further, the nature of state power-the power of the civil service and informal patterns of statebusiness interactions-shape business strategies in subtle ways. I go on to analyze the impact of federalism. The last section analyses how competition in the business sub-system shapes the emergent associations as well as contributes to the absence of associational consolidation in India. The conclusion ties the main argument together.

\section{An Alternative Framework For the Rise of a Developmentally-Oriented Association in India ${ }^{22}$}

In January 1992, the then engineering association, Confederation of Engineering industry (hereafter CEI) transformed itself into Confederation of

\footnotetext{
${ }^{20}$ The concepts in this table are drawn from a rich comparative political economy literature; some of its salient authors are: Schmitter and Lehmbruch (1979); Lehmbruch and Schmitter (1982); Amsden (1989); Johnson (1982); Evans (1995); Rudolph and Rudolph (1987); Herring (1999); Krueger (1974); and Alavi (1982).

${ }^{21}$ India has mostly been perceived to have a strong autonomous state but its divided structure also lends it to be in the right hand box.

${ }^{22}$ This analysis relies on primary fieldwork conducted in India, a newspaper database constructed by the author from six to eight Indian newspapers for the period 1990-2004, primary published and unpublished documents of the various business associations, and repeated interviews with members of the various business associations.
} 
Indian Industry (hereafter CII) seeking to represent the entire industrial sector. This transformation was not without its naysayers. In fact, its largely engineering membership base was not supportive of such a move and a consultant hired to evaluate whether the association should go this route had recommended against such a transformation. ${ }^{23}$ At the time, national economic policy was in transition and it was not very clear what the new role and tasks of such an organization would be. Initially, the transformation was more in change of name than in fact: In 1992 the association had only 100 non-engineering members out of a total membership of 2600 , less than 4 percent, and the organization found it difficult to go beyond its engineering base. ${ }^{24}$

Despite these uncertain beginnings, the association over time came to acquire a prominence, and was recognized to be a key partner for many of the government's policy initiatives. In March 2004, 12 years after its transmutation, Tarun Das, the Director-General of CII was asked: "What has been your most momentous achievement?" He replied: "I think, the really big occasion for us was to transit from an engineering association to being CII. That opened the window very wide and created so many new opportunities." ${ }^{25}$ CII expanded and diversified its membership base over time. In 1987, CEI's membership was 2005 companies, which grew to 2,567 in 1991 and to 4,700 in $2003 .{ }^{26}$ In 1991, it had few multinational members. By 2003, attracted by its political influence, 305 multinational companies had joined the organization. ${ }^{27}$ By 2003, engineering industries were about 50.3 percent (around 2,365 firms) of its total members $\left(4,700\right.$ members), a sharp decrease from $1992 .{ }^{28}$ It is also worth noting that a large majority of CII's membership base- $\mathbf{9 5 . 3}$ percent-has joint venture collaborations, mostly with foreign firms. ${ }^{29}$

A growth in membership corresponded with an expansion in the scope of its activities. By 2004, it seemed to have a finger in every pie from "social sector

\footnotetext{
${ }^{23}$ Interview with CII official, August 9, 2003. This was confirmed in newspaper reports of the time. Interestingly, in 1991, given opposition from its members to such a move, the President of CEI was forced to clarify that, "The Confederation will continue to widen its base without shedding its industry-specific identity. He also ruled out a change in the name of his organization to Confederation of Indian Industry (CII) as suggested by some." "CEI to Pressure Opposition to accept Reforms Package,” Business Standard, 1 July 1991. By December 1991, CEI had changed its name to CII.

${ }^{24}$ CII, Annual Report, 1993. Interview with senior officials of the CII who had been with the organization since the mid 1980s.

25"Interview with Tarun Das by Shubhrangshu Roy," March 26, 2004 http://economictimes.indiatimes.com/articleshow/582280.cms (Accessed on March 28, 2004).

${ }^{26}$ Annual Report, 1991; Annual Report, 2003.

${ }^{27}$ The total list of multinational company members of CII is with the author.

${ }^{28}$ Author's calculations from CII, Membership Directory, 2003.

${ }^{29}$ Calculated from CII, Membership Directory, 2003. Pedersen noted a similar finding for the year 1992 (Pedersen 2000).
} 
development," to "security dialogue, ${ }^{30}$ to election participation awareness campaign, ${ }^{31}$ to a meditation cell. ${ }^{, 32}$ It was active internationally and bilaterally, responding to a wide array of security and economic crises faced by India. ${ }^{33}$ It was especially active in the United States and began to engage the US domestic political process quite intensively. ${ }^{34}$ The association along with FICCI was invited to all the key national level advisory bodies and became part of the official government's delegation to the World Trade Organization (WTO) in 1999 at Seattle. ${ }^{35}$ CII, together with FICCI, came to represent the most prominent sections of Indian business, relegating Assocham to third rank. It seemed as if business in India had 'solved' its collective action problem and become a joint partner of the Indian state.

Within the context of a neo-instititionalist framework, CII represents a classic example of a "developmental association" responding to crucial market and state failure challenges. ${ }^{36}$ It supports the ongoing economic reform process pressuring the government to provide infrastructure (e.g. power sector reform) and a non-corrupt administration. It self-consciously abjures distributive and particularistic needs of its individual members, claiming that no narrow and individual specific demands of members are defended in front of the government. ${ }^{37}$ It initiated a quality movement among its member companies and provided crucial marketing information and other information to its member companies.

\footnotetext{
${ }^{30}$ CII, Annual Report $(2003,16)$.

${ }^{31}$ As part of its "corporate social responsibility program" CII requested cellular operators to send a SMS message to around 35 million voters reminding them to exercise their franchise on polling day in India (April-May 2004). "CII To pitch in with SMS to Alert Voters," The Financial Express, 22 April 2004.

${ }^{32}$ The CII, Annual report noted in a section titled, "New Frontiers," that the CII-Southern Region had signed a memorandum of understanding with the "Indian Centre of Meditation and Dispute Resolution' for creating "awareness about the potential of meditation as a preferable means of dispute resolution and to get industry personnel trained in matters of meditation." See CII, Annual Report $(2002,24)$.

${ }^{33}$ For example, it played a major role in diluting opposition to India's nuclear tests (of 1998) in the US Congress.

${ }^{34}$ Tarun Das, chief mentor of the Confederation of Indian Industry, Kiran Pasricha, CII's senior director for North America attended the Democratic Party Convention in Boston, out of only 4 people working on India to do so. See K.P. Nayar, "India Should Use Political Events in the US to its Advantage," The Telegraph, 11 August 2003.

${ }^{35}$ As part of the government's delegation, two members of CII were allowed to be part of the Ministerial deliberations in an advisory capacity.

${ }^{36}$ Vanita Shastri argues that CII is a developmental organization (1997). Also see Nayar (1998; 2001), Pedersen (2000); and Kochanek (1995-1996).

${ }^{37}$ Officials at different levels of the organization stressed this. Government officials also admit that CII demands usually relate not to one or two members but to an entire sector or industry. This does not mean that no member makes such requests but the secretariat seems to have resisted such internal pressures for the pursuit of narrow particularistic benefits.
} 
How did a narrow organization concerned only with its own specific sector transform itself and become developmental? Interpretations that focus on organizational attributes of the organization or functional needs arising out of globalization are unable to explain the politically contested process through which CII came into being and rose to prominence. The functional explanation may explain why the organization became useful to policymakers; it does not, however, address the question of why and how such an organization came into being. It is clear that we need an independent theory of business development in dirigiste yet pluralist systems; such a theory must be able to account for change over time, and offer a set of assumptions about incentives and interests of state and business actors. Thus, what contextual conditions stimulate developmental versus predatory associational activity needs to be theorized more systematically.

\section{Distribution of Power, the Indian State, and Business Associations in India}

Counter-intuitively for our expectation of India where distributional coalitions are considered to be strong, but in line with Schneider's (2004) recent arguments, state actors facilitated the rise of CII as a competitor organization to FICCI. Moreover, and even more interestingly, state structure (federalism) and the pattern of state power shaped the activities and strategies of emerging and reforming business associations alike. Over time, state actors, by sponsoring different organizations at different points in time, enhanced the competitive fragmentation within the business sector of the Indian economy. The Indian state played a crucial role in transforming CEI from its engineering focus to an allindustry focus and in giving it importance. In the mid 1980s, the state leadership deployed the CEI to further its reform program. Further, the Indian prime minister gave access, symbolic importance, and explicit tasks to CEI at a crucial moment in its development.

In 1985, Rajiv Gandhi was elected as India's new prime minister with a massive mandate and introduced a reformist agenda. He initiated significant economic liberalization despite serious opposition from his own party members and a history of dirigiste economic policies in India. ${ }^{38}$ His reform program aimed at technological modernization, external opening as well as a reduction of state regulation. The most important of these included a relaxation of the restrictive licensing arrangements, a new fiscal policy aimed at promoting investment and research, and liberalization of foreign exchange rules to promote the inflow of finance and technology transfer from abroad. While limited, his reform program represented one of the first serious attempts to reorient India's economic strategy toward more openness and competition. In this quest, he renewed links with the newly emerging business association, the Association of Indian Engineering Industry (AIEI), CII's predecessor. FICCI, in contrast, was protectionist, weak,

\footnotetext{
${ }^{38}$ See Kohli (1989) and Harriss (1987) for an analysis of the 1985 reform program.
} 
and fractionalized and had acquired vested interests in the continuation of the regulatory system rather than its withdrawal. ${ }^{39}$ Rajiv Gandhi needed an organization that was outside of the pre-existing business-state networks, not troubled by factional politics, and could support his reform program. AIEI, till then, was based in Calcutta and was a relative outsider to the business-politics nexus centered in New Delhi. Most importantly, AIEI's international activities resonated with Rajiv Gandhi's reform program, which stressed technological integration with the West; in contrast, FICCI was relatively more inward looking in its orientation. AIEI had initiated global linkages with international organizations, other business firms, and groups in the mid 1970s. ${ }^{40}$ AIEI and CEI's organizational culture and outward orientation resonated with Rajiv Gandhi's clean image and reformist agenda.

Most importantly, Rajiv Gandhi needed AIEI when he faced significant opposition from within his party and the bureaucracy for his reform program. Most of his close advisors were perceived to be technocratic and out of touch with the masses. Lacking any supporters within a conservative bureaucracy, and facing a resistant party, Rajiv Gandhi needed allies and support for his nascent reform program as well as crucial information. ${ }^{41}$ Rajiv Gandhi used the various forums facilitated by CEI to publicize his reform program. As an illustration, in 1988, he spoke at a conference organized in New Delhi by CEI on the need to simplify procedures and ensure efficiency in attracting foreign investment. ${ }^{42}$ CEI's leadership publicized and circulated his ideas to the business community. In 1988 Tarun Das, CEI's Director-General, spoke about the ongoing reform program in extremely positive terms at several places: "Rajiv Gandhi is the first Prime Minister we've had who understood the private sector. He is trying to take us out of our cocoon and expose us to the real world."43 On the basis of his consultations with AIEI Rajiv Gandhi transferred responsibility for company affairs from the Ministry of Justice to the Industry Ministry. The aim was to remove a major bottleneck in approval of industrial licenses, which was a major hazard for businessmen in India. Mr. Tarun Das said at that time, "This was a small but significant step for domestic and foreign investments and joint ventures. These

\footnotetext{
${ }^{39}$ I analyze FICCI's weakness below.

${ }^{40}$ In 1976 AIEI started organizing international trade fairs, which allowed their member companies to initiate international joint ventures and seek export markets. They also started interacting with business associations in other countries and opened international offices: By 1988 they had four offices in international cities; by 2001 they had 11 such offices. CII also began co-sponsoring the World Economic Forum's India's Summit, which became a high profile event in the 1990s.

${ }^{41}$ The opposition to Rajiv Gandhi's reform program has been extensively researched: Kohli (1989); Harriss (1987); and Varshney (1999).

${ }^{42}$ The Financial Times, $20^{\text {th }}$ April 1988. Also see, "The Indian Government is Set for a More Relaxed Approach Towards Foreign Investment," The Economic Times, 22 April 1988.

43،"India's Tentative Turnaround," The New York Times, 29 May 1988.
} 
would now be approved six months to two years earlier." ${ }^{44}$ Thus, Rajiv Gandhi used the organization as a platform to launch his reform program and to gain support from India's business community. At that time public sector engineering firms dominated AIEI and CEI; by encouraging this organization, he was able to spread his ideas to a sector which was expected to resist some of the changes planned by him.

Over time, other state actors have continued to use business associations to initiate and publicize difficult policy change. In the early 1990s, Manmohan Singh, the then Finance Minister and part of a minority government, was faced with a similar opposition to his reform program in parliament, where he depended upon crucial support from opposition parties. He recommended that CII popularize his ideas of economic reform to the opposition parties in parliament. CII started organizing forums for parliamentary parties in the early 1990s and has continued that practice ever since. ${ }^{45}$ Again, in December 2001, prime minister Atal Bihari Vajpayee asked CII to invite Benazir Bhutto, Pakistan's former prime minister to India when it was politically difficult for Vajpayee to take ownership for that invitation. ${ }^{46}$ Again, after India's nuclear tests (in May 1998), Vajpayee requested CII to use their US connections to change US public opinion in favor of India. ${ }^{47}$ In 2003-2004, CII set up a WTO cell in Geneva; Arun Shourie, the then Minister of Disinvestment and Commerce, suggested that CII monitor the WTO process more closely. ${ }^{48}$ In 2004, P. Chidambaram, India's Finance Minister, asked the business chambers to convince the left parties in the coalition government to support an increase in the Foreign Direct Investment cap in the insurance sector. He said: "I would like CII and FICCI to address some of our friends in the Left parties and convince them (that the move is progressive)."

AIEI's meteoric rise to power in the 1980s and 1990s can be directly traced to the access and importance facilitated by Rajiv Gandhi. In 1985, Rajiv Gandhi agreed to address the AIEI annual meeting although he had refused a similar invitation from FICCI. ${ }^{50} \mathrm{He}$ encouraged CEI to submit concept, 'theme,' and policy papers to the government, which began to introduce business oriented perspectives in the government and also support his reform program. ${ }^{51}$ Rajiv

\footnotetext{
44،"India to Go Ahead with Election,” The Financial Times, 10 November 1984.

${ }^{45}$ Interview with CII officials.

${ }^{46}$ Confidential Interview, Washington DC July 2005. In December 2001, she visited India on a "private visit" on the invitation of CII soon after the august summit between Pakistan's president Musharraf and India's prime minister Vajpayee.

${ }^{47}$ Confidential Interview with author, Washington DC, July 2005.

${ }^{48}$ Interview of a senior CII official with author, New Delhi July 17 2003. Interestingly, in the late 1990 s, CII had rejected a similar recommendation by a prominent journalist.

49،FDI insurance: UPA Hopes BJP Will Return Earlier Favour, Indian Express, 13 July, 2004.

${ }^{50}$ Kochanek (1995-1996).

${ }^{51}$ Interview with senior CII officials. One government official told me: "We needed different views to stir things up a little; otherwise, Rajiv Gandhi's program would have gone nowhere. We
} 
Gandhi even played a role in the transformation of the organization from an engineering association to an all-industry association. Rajiv Gandhi suggested that CEI represent all industry and move beyond its engineering focus. He is reported to have told the Secretary-general, Tarun Das: "You are doing good work. I like the work you are doing. Why don't you transform into a general industry association?",52 The secretariat took this proposal to its members and faced some opposition to this change from within. This led them to hire a consultant to evaluate whether such a change was desirable. ${ }^{53}$ The consultant recommended that the CEI retain its focus as an organization servicing the engineering industry; he argued that the transformation would be deleterious for their engineering members leading the association to lose focus. After many deliberations and discussions within the association, a decision was taken to override the decision of the consultant and make the organization represent the whole of Indian industry. Rajiv Gandhi's sponsorship and the access and power such a linkage would provide was a major reason for overriding the recommendation of the consultant. ${ }^{54}$ Thus, the prime minister played a major role in transforming an engineering association into an all-purpose industry association.

His close relationship with the members of the body allowed the association to acquire political access and influence, which were then denied to other bodies. Rajiv Gandhi added credibility to the AIEI when he invited AIEI leaders to accompany him on a trip to the Soviet Union (Kochanek 1995-96). This was the first time that a business delegation accompanied India's prime minister on an official foreign trip; Rajiv Gandhi facilitated this inclusion despite serious opposition from within the bureaucracy. On hearing of AIEI's inclusion in the PM's entourage, the Indian Ambassador to the USSR (1983-1986), Nurul Hasan is reported to have telegraphed back his displeasure. ${ }^{55} \mathrm{He}$ told the government: "The private sector businessmen cannot be part of a state delegation." Rajiv Gandhi, on hearing this, told the foreign ministry officials to "throw the telegraph in the dustbin" and proceeded to take the AIE members with him. ${ }^{56}$ This action

needed to break down shibboleths and narrow assumptions about government's role, the public sector and the like. Input from a different business organization was necessary to this task. So, he encouraged them and invited them to submit recommendations and concept papers." Interview with author, New Delhi, July 13, 2003.

${ }^{52}$ This information comes from confidential interviews. I crosschecked this information from a number of sources and this was confirmed independently in different ways.

${ }^{53}$ Prof. S. K. Bhattacharjee of Management Structures and Systems, Mumbai was the consultant hired for the job.

${ }^{54}$ Interview with CII officials, New Delhi, and San Francisco, June 3, 2005.

${ }^{55}$ Nurul Hasan was a powerful member of the CPI, hostile to business and close to the Congress Party. He occupied various key posts; in the mid 1980s he was India's ambassador to the USSR.

${ }^{56}$ Interview of a very high level member of CII with the author, $2^{\text {nd }}$ June, Stanford University, USA. 
gave AIEI direct political access, a "selective benefit" of representation in a foreign public policy forum and informal power in their future interactions with other state functionaries. ${ }^{57}$ Rajiv Gandhi continued to lend public support to many of AIEI's and CEI's ideas. ${ }^{58} \mathrm{CII}$ used these early political and bureaucratic contacts within the central bureaucracy to build regular-both formal and informal-relationships with key elements within the state. Tarun Das recognized the pivotal role played by Rajiv Gandhi [1985-1989] in CII's rise. He said: "In 1986, I don't think CEI was seen as one of the front-ranking organizations. But between 1986 and 1991 this has been achieved." ${ }^{, 59}$ Recently, he said: "That period [Rajiv Gandhi's prime minister-ship] was a crucial period for us [CII]." ${ }^{\circ 0}$ Thus, the transformation of CII as an industry-wide organization owes in no small part its existence to the reformist proclivities of the prime minister, who chose to patronize the AIEI (and its later incarnation, the CEI) when he needed reformist allies.

Analogously, the expression of state displeasure and withholding of access has a powerful impact on business associations. After Gujarat riots in February 2002, CII organized a meeting where some of its own members expressed criticism of the Gujarat government's chief minister. This public criticism created a serious rift between $\mathrm{CII}$ and the Gujarat government, which even extended to a cooling of relations with the BJP-led national government. After this withdrawal of state access, Tarun Das personally visited Gujarat's chief minister, Mr. Narendra Modi and apologized to him. ${ }^{61}$ Despite support from within the organization for a more public criticism of social violence in Gujarat, CII has decided not to criticize the state government. In 2004, CII even invited Narender Modi, Gujarat's chief minister, to its high profile, India Economic Summit, organized with the World Economic Forum, in an effort to patch up its differences

\footnotetext{
${ }^{57}$ This confirms Schneider's argument that, "State actors are the central protagonists in encouraging the formation of voluntary, encompassing associations, sometimes unintentionally, and more importantly, intentionally, by offering associations selective benefits such as representation in policy forums or authority over public functions or funds (Schneider 2004, 11)."

${ }^{58}$ For example, in 1986, AIEI came up with a proposal to build Andaman and Nicobar islands for tourism and industry purposes. Rajiv Gandhi supported this proposal at a news conference in Dubai.

59، An Uncanny Ability to Anticipate Events: An Interview with Tarun Das," Business Standard, 12 January 1992.

${ }^{60}$ Interview with author, $2^{\text {nd }}$ June 2005 . Publicly, CII credits the 1991 reform program as being responsible for its rise and transformation but CII's rise to power had preceded the 1991 liberalization program.

61“"A Sorry Sight," Business Standard, 10 March 2003; "Mr. Modi and CII: the Wages of Crony Capitalism," The Financial Express, 11 March 2003; "After CII, FICCI Reprieve, Promise of Help for Modi," Indian Express 14 March 2003. I confirmed this in confidential interviews with CII officials.
} 
with the government and BJP. ${ }^{62}$ Thus, state facilitation of political access and its withdrawal has a powerful impact even on institutionally strong associations like the CII. The state continues to shape the power, activities, and the discursive strategies of business associations in India.

Even more importantly, the nature of state power and its informal workings affect the tactics and mechanisms of influence deployed by India's business associations. In India's parliamentary system, the civil service is permanent and powerful. This led the leadership of CII to interact with the civil service through many diverse channels. Tarun Das revealingly said in an early interview: "We have consistently had a policy of working with the civil service that is there at the centre and the States. We find that they are the administration, they are the prominent people there. And, therefore, we feel that while we must address the political level. . . and we do that but on a continuous basis, there is a continuous dialogue and interaction with the bureaucracy at all levels." ${ }^{63}$ Second, CII had to adapt to the informal ways in which the business-politics relationship has evolved in India. Tarun Das himself emphasized this in an interview outlining the process of re-working the FERA [The Foreign Exchange Regulation Act] in 1991-1992. "The FERA is being revised and re-drafted. And, we found out who are the two or three officers behind the scene. We have a core group on FERA. We arranged an informal briefing between the core group and the people in the government working on the re-drafting of the FERA. Our meetings are-informal, off-the record, not for publicity at all. We are very conscious of the fact that when we have informal discussions with the government, we don't go for media coverage on that. And, we try to build up this relationship of mutual trust very very carefully and we try to earn that trust through our actions. ${ }^{, 64}$ Responding to a question about the strengths of CII, Tarun Das, further noted: "We spend a lot of time interacting informally with the government. Apart from representations, we give a lot of time to informal discussions." ${ }^{, 65}$ A close observer of CII's success said: "CII and Tarun Das understand the nature of Indian system perfectly. He is the chairman of a company and knows the nitty gritty of India's business environment. He has his pulse on its very specific and informal workings. He knows how it works and how to get around it." ${ }^{, 66}$ Third, given India's strong state traditions, business associations present themselves in subsidiary roles rather than independent interlocutors to the government; the discursive rhetoric of

\footnotetext{
62“'Mobbed, Modi Shows 'Civilized' Face,” The Telegraph, 22 December 2004. The report noted that the protestors at the summit urged Rahul Bajaj, the person who had expressed his criticisms in 2002, to join the protests but he declined. Also see, "Modi Runs into Protests at WEF," November 24, 2003, http://in.rediff.com/news/2003/nov/24modi.htm

63، An Uncanny ability to Anticipate Events: Interview with Tarun Das," Business Standard, 12 January 1992.

${ }^{64}$ Ibid. Emphasis Added.

${ }^{65}$ Ibid. Emphasis Added.

${ }^{66}$ Interview with Author, December 15, 2004, Washington DC. The interviewee stressed this point.
} 
associations even in the globalization era is shaped by the dominant nature of state power in India. Thus, CII has described the association's relationship to the government as "the junior partner of the government." ${ }^{97}$ Its officially stated principles are: "partnership with government" and a "consensus approach.", 0 One of the reasons of the success of CII is its ability not to be seen criticizing the government in international or even domestic forums. CII claims to have a supportive and collaborative approach rather than a confrontational approach to its working with the Indian government. ${ }^{69}$ As one CII official put it: "We do a lot, I mean, a lot, of quiet lobbying and even criticizing the government but we never publicize it. ${ }^{70}$ Thus, CII's emergence and success in breaking into a pluralistic interest group arena dominated by many organizations owes itself to crucial sponsorship by the prime minister, and his reformist allies. This opening up of the political opportunity structure in the mid 1980s led to the rise and transformation of AIEI into CEI and then CII. Reciprocally, Rajiv Gandhi's reform program represented an opening in the political opportunity structure of the Indian state for the smaller, external association and CII was able to convert its outside status and informal connections to its advantage only because it adapted to the nature of state power in India's political economy.

\section{The Impact of India's Federal State on Business Associations in India}

In addition, the institutional form of the Indian state, for example, its federal structure, affects the organizational form, tactics, and activities of CII as well as other associations. ${ }^{71}$ The federal "opportunity structure" of the Indian state

\footnotetext{
${ }^{67}$ Tarun Das characterized it thus: "We look at it this way: development is a partnership process between government and industry. And we are the junior partner of the government." "Interview with Tarun Das: An Uncanny Ability to Anticipate Events," Business Standard, 12 January 1992.

68“CII, A Profile," Found in Directory of CII members, 2003, Available with author.

${ }^{69}$ This was stressed in all my interviews with CII officials. This point is also noted by Kochanek (1995-1996).

${ }^{70}$ Interview with a high level official of the CII, August 2003. New Delhi. The one exception was the debate over Gujarat riots. In 2001, the CII organized a forum in which criticism of the Gujarat government response to the riots in Gujarat was expressed. This created a huge public relations quagmire for CII as the Gujarat CM showed its anger against the CII and many BJP government officials expressed their displeasure at CII's sponsorship of the event.

${ }^{71} \mathrm{~A}$ similar impact of federalism on the organizational structure of business associations may be found in other federal countries. In Brazil the major industry confederation, CNI, was composed of 27 state level federations, each with one vote similar to the equal representation of its provincial units in its national senate (see Schneider 2004, 94). Similarly, in Germany, the BDI is the umbrella organization of German industry and industry-related service providers and has 15 regional offices in the German Länders (provinces) [http://www.bdi-online.de/]. In the United States, the NAM (National Association of Manufacturers) and the US Chamber of Commerce all have offices in the 50 states (The US Chamber of Commerce has 2,800 state and local chambers). See, http://www.nam.org and http://www.uschamber.com.
} 
is mirrored in the multi-level structure adopted by CII. CII's organization consists of regional offices, state offices and a national office similar to India's political structure. ${ }^{72}$ Interestingly, CII's predecessor, AIEI, was first noticed by Rajiv Gandhi at an AIEI organized event with the Uttar Pradesh government in 1983; this led to a long-standing relationship between the two. ${ }^{73}$ CII's offices organize events and activities for the local state governments and seek favors and interactions with them. CII's activities and structure especially respond to resurgent provincial demands for economic reform in India's "federal market economy." "74 In 1995, CII organized its centennial "Partnership Summit" in Calcutta (West Bengal), publicizing the West Bengal government's liberalization policy to the outside world. It, in concert with the state government, signaled that a radical change in West Bengal reflected a credible and permanent change in its policy orientation in favor of liberalization. Ever since then, it has held numerous partnership summits (an annual event); the last two (2003 and 2004) have been in association with Chandrababu Naidu, the then chief Minister of the state of Andhra Pradesh and the latest one was held in association with West Bengal (2005). CII has provided national and even international forums for state chief ministers to publicize their state's industrial policies to the domestic and international arenas; in the process, enhancing CII's prestige and embedding the density of interactions between the local leadership and the global arena. ${ }^{75}$ Thus, in a federal country, CII has played a major role in disseminating support for liberalization across India's states and in ensuring that opposition to the reform does not coalesce into a full-scale movement against the reform process. $^{76}$ Interestingly, this also created duplication and the coordination dilemmas with each CII provincial office organizing similar events simultaneously. ${ }^{77}$

With an increasing role played by regional states in the ongoing liberalization process, FICCI has also found itself initiating parallel activities at the subnational level. ${ }^{78}$ In 1996 FICCI set up zonal offices, which were further re-

\footnotetext{
${ }^{72}$ The organizational structure of CII can be found at www.ciionline.org

${ }^{73}$ Interview with CII official, $2^{\text {nd }}$ June 2005, San Francisco.

${ }^{74}$ Rudolph and Rudolph (2001).

${ }^{75}$ This is true of Bihar, Rajasthan, Tamil Nadu, West Bengal, and Andhra Pradesh.

${ }^{76}$ For a fine-grained understanding the process by which economic reforms have become sustainable in India, see Jenkins (1999).

${ }^{77}$ Interview with CII officials, Washington DC May 2005; New Delhi, 27 August 2003; and Bombay, May 2003.

${ }^{78}$ FICCI, a federation of regional and sectoral chambers, is at heart a federal organization but its loose relationship with the much more independent regional chambers meant that coordination across levels (between the regional chamber and the national FICCI office) remained infrequent. Each of the regional chambers and their own name, constitution, administration, and finances and were only loosely associated with FICCI. Thus, state level activities of the FICCI were conducted under the aegis of the regional chambers rather than under a unified banner of FICCI.
} 
organized in $2003 .^{79}$ In 2003, FICCI decided to set up three regional and eight state-level offices to "deepen its state level activities." 80 This was partly in response to the increasing role played by states in shaping liberalization ${ }^{81}$ and partly in response to the fact that CII had regional and state offices and quite significant state-level activities. As Dilip Salvekar, the Joint Secretary-General of the Maharashtra Chamber of Commerce and Industry said: "Being the financial capital, we needed an organization like FICCI which is involved in national and international issues. It is most appropriate that FICCI should come to Mumbai since other national level chambers like Assocham and CII are already here." 82 The power of the existing institutions to shape the nature and organizational form of business associations speaks to the importance of historical institutionalist arguments: institutions in India-both formal in terms of federalism and informal norms about state-business interactions - constrain as well as enable associations. These two elements-reformist leadership within the state (Rajiv Gandhi's role), and openings provided by the federal structure-encompass the changing "political opportunity structure" that gave birth to a new and developmental organization in India. To this state-centric analysis we must add another aspect of the political opportunity structure: changes in the competitive environment of business, that is, the enhanced inter-associational competition in 1980s and 1990s India.

\section{Inter-Business Competition in India}

The business competitive environment provided a powerful context for the rise of the CII; interestingly, this inter-business competition for political access and power continues to shape the form and patterns of collective action in India to this date. ${ }^{83}$ While globalization created a functional need to unify associations, the politics of competition prevented such unity and coherence; business associations in India continue to be fragmented and to compete intensely. ${ }^{84}$

First, in the late 1980s and early 1990s, the business system entered a competitive and transitional phase with internal churning within the existing and

\footnotetext{
79،"FICCI Setting Up Zonal Offices to Address Regional Issues,” The Pioneer, (New Delhi), 24 March 1996.

${ }^{80}$ Rajeev Jayaswal, "FICCI Setting Up Regional Offices," The Financial Express, 4 September 2003. The state level offices were to be set up in Mumbai, Goa, Ahmedabad, Chennai, Bangalore, Kochi, Hyderabad, and Raipur.

${ }^{81}$ Jenkins (1999); Saez (2002); and Sinha (2005).

${ }^{82}$ Rajeev Jayaswal, "FICCI Setting Up Regional Offices," The Financial Express, 4 September 2003.

${ }^{83}$ In speaking of competition between associations I focus on competition among organizations for political access and to the state; in this paper I do not explore intra-business competition for members etc.

${ }^{84}$ For an account of how globalization affects collective action see Cerny (1995).
} 
predominant business association (FICCI) and the revitalization of another business association (Assocham). This provided the initial window of opportunity for a new organization to enter the associational marketplace by providing many developmental services to both the government and the industry. Second, both the existing organizations-FICCI and Assocham-were confronted with a history of intra-organizational challenges and weaknesses that made it possible for a reformist leader (Rajiv Gandhi) to encourage the transformation of a sectoral association and cultivate this association. This competitive encouragement of a relative outsider association set into motion the process through which the structure of the "business system" changed radically in India. Both these factors combined to create the ripe political context for the rise of CII.

In the late 1980s and early 1990s, the existing apex organization-the FICCI-had weakened. FICCI had been subject to internal infighting and conflict for almost a decade, but in the mid 1980s, the infighting had broken out again and in 1987, the association underwent a split when the Bombay group within FICCI left the organization (Kochanek 1996-1996; 1996). These Bombay business groups joined Assocham, revitalizing the declining organization in the process. Thus, the late 1980s and the early 1990s saw a competitive and transitional "business system" when internal crisis within one of the premier associations (FICCI) revitalized another (Assocham). Simultaneously, the internal fragmentation of the existing associations allowed a sectoral association to acquire prominence and institutional strength somewhat disproportionate to its actual power at that time.

The late 1980s and early 1990s saw enhanced competition between FICCI and Assocham, which recurs periodically. The Bombay business houses-some prominent members of the industrial elite in India-had left FICCI after an internal fight over bogus membership and the control of decision-making within FICCI. They joined Assocham, in the process revitalizing it with resources, talent, and new ideas. Assocham saw a significant influx of money and talent into the organization. ${ }^{85}$ Thus, when the CEI thought of catering to the needs of the wider industry, it first thought of a merger with Assocham. ${ }^{86}$ This would have made the

\footnotetext{
${ }^{85}$ See, "Significant Increase in ASSOCHAM Membership," The Patriot, 9 July 1990; "Big Rise in ASSOCHAM Membership," The Hindustan Times, 9 July 1990; "Sharp Rise in Assocham Membership," Business Standard, 9 July 1990. The annual revenue of Assocham increased from 25 lakh to 1 crore as a result of the increase in membership. Also, see "Assocham to Enlarge Membership," The Telegraph, 26 November 1990; "Assocham Membership Doubles," The Financial Express, 27 November 1990; "Assocham to Have Enlarged Panel," Business and Political Observer, 27 November, 1990; "Membership of ASSOCHAM Crosses 50,000," The Times of India, 16 May 1991.

86“CEI May Merge with Assocham, Change Name," The Economic Times, 15 May, 1991; Subir Roy, "CEI, ASSOCHAM Merger Move: Industry Eager to Speak with One Voice," The Economic Times, 16 May 1991; "Merger of Assocham and CEI Welcomed," The Independent, 18 May 1991;
} 
unified body a very powerful organization. Assocham's president at that time expressed the desire and need to unite business voices in India. This, he felt, would increase the power of business vis-a-vis the government. He pointed out:

Countries, which have made the most progress in the postwar era like Japan, Germany and France, have fundamentally one chamber, which is very powerful and is consulted in policymaking. The Japanese PM sometimes even comes to meet the head of Keidanren, the apex body of the captains of industry. The German and Paris chambers of commerce are almost a part of the respective governments and the status of the British Confederation of Industry is well known. ${ }^{87}$

Simultaneously, the competition between the two main national organizations had heated up. FICCI's sponsorship of the joint business councils, involving cooperation and networking with business actors from other countries as well as the government officials, was a source of envy for members of other associations. Members of CEI felt that their exclusion from these councils, and their monopolization by FICCI, was unfair. ${ }^{88}$ Competition was also evident through the movement of members from one organization to another. After 1987, Assocham saw the entry of many new members, other chambers, and big corporate houses. From 1987 to 1991, the direct membership doubled to 500 and the indirect membership increase eightfold to 52,000. In 1991, nine more big companies became the "patron members" of the association. ${ }^{89}$ These included a wide array of industrial companies that gave added prestige and reputation to the organization. After this induction, Assocham enjoyed the patronage of such companies as Tata Sons, Bajaj Auto, Mahindra and Mahindra, Chowgulke and Co, Hindustan Lever, ITC, Philips Carbon Black, (RPG), Shaw Wallace and Company, Premier Automobiles, The Mafatlal Spinning and Company, The MRF, Modi Xerox, DLF Universal, Indian Aluminum, and the Amalgamation Ltd (Simpson group). Many of these companies had left the FICCI and joined Assocham, thus putting a competitive pressure on FICCI. ${ }^{90}$ It could be argued that CEI through this transformation wanted to replace FICCI as the single most powerful industry association in the country. ${ }^{91}$ Increased competition between

"CEI Changing Name to take on FICCI, Assocham," Business and Political Observer, 7 November 1991.

${ }^{87}$ Subir Roy, "CEI, ASSOCHAM merger move: Industry eager to Speak with One Voice," The Times of India, 16 May 1991.

${ }^{88}$ Interview with CII official, New Delhi, 23 August 2003.

"Nine more Companies Join ASSOCHAM," The Statesman, 18 February 1991; "9 Big Companies Join Assocham," The Hindustan Times, 18 February 1991.

${ }^{90}$ See, "More Companies Join ASSOCHAM," 18 February, 1991 Times of India; "New Assocham Patron Members," The Independent, 18 February 1991; "ASSOCHAM Gains 9 More Members," Indian Express, 18 February 1991.

${ }^{91}$ A. Thothathru Raman, "CEI Changing Name to Take on FICCI, Assocham," Business and Political Observer, 7 November 1991. Also see, Indranil Ghosh, "Renaming CEI Raises Many an Eyebrow," The Financial Express, 4 January 1992; S. Roy, "Muscling into the Top," Business 
FICCI and Assocham provided a rare opening for organizations like CEI to think about entering the competitive fray, and they did.

\section{Competition and Developmental Transformation}

The specific business-politics relationship in late 1980s and early 1990s India shaped the nature of the new organization that took shape. Historical conjuncture mattered. Up to that point, India's regulatory system and the business-politics relationship were analogous to a political exchange: in exchange for specific favors, business actors supported governments and politicians. The government's role was overly regulative and the business associations sought only particularistic benefits for their firms or sectors abandoning any governance or developmental activities. Thus, India came to be invoked as a classic "rentseeking society" and its business-state pattern characterized by "embedded particuralism." ${ }^{\circ 3}$ This larger pattern contributed to the organizational malaise in which FICCI found itself. By the late 1980s the weakness of existing associations, specifically their inability to provide any value-added to their members and to facilitate long-term development of the economy, had become apparent. Most business associations in India served the interest of few powerful business groups rather than their larger membership base or needs of a reforming government. AIEI/CEI, excluded from this system, sought to distinguish themselves by providing key developmental services to their members and sought international access. With the opening in the system and Rajiv Gandhi's ascent to power, CEI articulated a new 'business model' of associations, which would provide services to the government as well as its members. Given the political factionalism of the existing associations, CEI organized a strong secretariat-led organization, which would keep above the fray of infighting among business houses. In doing so, they offered a distinct organizational and service model to the government and existing associations (FICCI and Assocham), which were hounded by infighting and political interference by powerful business houses within their organizations. Most crucially, this resonated with Rajiv Gandhi's reformist agenda, but also filled a major gap in India's associational marketplace for developmental associations. Simultaneously, Rajiv Gandhi sought reform-oriented policy and concept papers from CEI and encouraged them continue with their innovative services. Subsequently, state officials — both central and provincial—continued to seek their services and demand more developmental activities. Most importantly, CEI's membership base consisted of engineering firms, run mostly on professional lines that were engaged in extensive joint ventures and foreign

Standard, 12 January 1992; and "Chambers Vie with Each Other for Supremacy," Indian Express, 28 May 1992.

${ }^{92}$ Kruger (1974).

${ }^{93}$ Herring (1999). 
collaborations. They demanded quality-oriented services from their secretariat and access to foreign markets. Once CII began providing such services, and with liberalization of the Indian economy, such services came to be more in demand. Thus, business competition in India took a developmental shape because it filled a crucial weakness in the then existing system, resonated with the reformist agenda of the then prime minister, and corresponded with the ongoing liberalization of the economy, where both markets and states needed information, governance input, and key services for the onerous transition. This historical form of associational transformation continued to shape subsequent changes initiated by other associations as greater competition fueled a 'race to the top' among business associations.

\section{Impact of Inter-Business Competition}

In response to the business model presented by CII, FICCI sought to organize itself and deal with the rise of CII, a powerful competitor. In 1994, the newly appointed Secretary-General of FICCI, Dr. Amit Mitra said: "I am glad that Tarun Das has worked wonders with the Confederation of Indian industry. It has helped wake FICCI up." ${ }^{, 4}$ Many of the reforms initiated by FICCI-campaign to expand membership and subscription, organizational changes, and changing purposes to deal with international competition-were in direct response to CII's perceived strengths. ${ }^{95}$ FICCI decided to go into the business of trade shows and exhibitions, a domain in which CII had already carved a name for itself. FICCI also started publishing a journal called 'Quality Trends,' following in the footsteps of CII's quality movement. ${ }^{96}$ In 1994 in an effort to strengthen its secretariat, a five-member core team was set up to oversee radical re-structuring of the administrative structures and procedures. FICCI decided to appoint an economic expert as a CEO who would also be the secretary-general. It was at this time that Dr. Amit Mitra was chosen to be the Secretary-General. ${ }^{97}$ Clearly, public relations and handling public events was prioritized given the positive publicity being received by CII. A new division titled, "Protocol" was set up to handle visits of foreign delegations besides looking after the other major functions of the chamber. "We want to give better hospitality and have proper management of

\footnotetext{
${ }^{94}$ Arif Sharif, "FICCI's Mitra Mantra," The Economic Times, 5 June 1994; Nandini Guha, "He is Bent on Making FICCI Fighting Fit," Financial Express, 16 June 1994.

95“"FICCI Wakes up to New Challenges," Business Standard, 5 January 1992.

96“"Chambers Vie with Each Other for Supremacy," Indian Express, 28 May 1992.

${ }^{97}$ Interviews; Also see, "FICCI Posed for a Major Restructuring Exercise," Indian Express, 12 May 1994; "FICCI Confirms Mitra as Secretary-General," The Economic Times 11 June 1994;

"Interview with A.K. Rungta: FICCI to Stress Promotional Work," The Hindu, 12 June 1994.
} 
important events," said, Mr. A. K. Rungta, a senior Vice President of FICCI. ${ }^{98}$ In 1998, a corporatist drive was launched to make FICCI a more efficient organization. The leadership of FICCI also began to track news stories on the two organizations and do a comparative evaluation of the media coverage of the two associations. ${ }^{99}$ Similar to CII, which seeks to make each of its divisions selfearning and profit oriented, it was decided that FICCI would run on a profit basis. ${ }^{100}$ In the mid to late 1990s, FICCI launched a new membership initiative especially with a view to shake off its "old economy image." In 2000, around 220 members from the so-called TMT (technology, media, and telecom) sectors joined the association including such companies as Infosys, S. Kumars, Aptec, Sony Entertainment Hughes Network systems, and Silverline Tech. Faced with competition FICCI realized that "unless we have a good membership base we will lose our voice as an apex industry chamber and also lack financial muscle."101 Reciprocally, a resurgent FICCI has begun to put competitive pressure on CII: Tarun Das recently said: "Yes we are very different from FICCI but their presence has kept us on our toes, we have to constantly innovate."102 Thus, competition within the business system shaped the transformation of existing organizations (in this case FICCI and Assocham) into developmental associations. Yet this competition prevented united collective action on the part of all three associations or any moves toward merger or unity. India, despite globalization and the transformation into developmental associations, continues to be a 'state dominated pluralist system' in which numerous groups vie for the state's attention and business is fragmented. Despite many attempts to unite business action, merger moves between CII, FICCI, and Assocham or even joint efforts or campaigns between the associations, could not succeed. ${ }^{103}$

The first such merger was mooted in June-July 1990, but came to naught. ${ }^{104}$ In July 1992, an apex committee constituted by the presidents of the three chambers-FICCI, CII, and Assocham-was proposed. It was seen as necessary to coordinate among the three chambers given economic liberalization, which had changed the role of the chambers from 'representation' to that of "partners of economic growth." The main task of the committee was to have joint

\footnotetext{
${ }^{98}$ Ibid. Also see, "FICCI Stops Buckling under New Initiative in US," The Economic Times, 18 May, 1994, "Showdown in FICCI, Secretary-General May be Replaced," The Economic Times, 11 May 1994.

${ }^{99}$ I thank John Echeverri-Gent for providing me with some information on this issue.

100“'FICCI Acquires New Economy Flavor,” The Times of India, 16 January 2001.

${ }^{101}$ Alop Mittal, advisor, FICCI. See, "FICCI Acquires New Economy Flavor," The Times of India, 16 January 2001.

${ }^{102}$ Interview with author, June 2-3, 2005, Stanford University.

${ }^{103}$ One exception was during the visit of the then prime minister, P.V. Narasimha Rao, to the US in May 1994 when all three chambers decided to put up a "united front." See, "Chambers to Put up United Front in US,” Business Standard, 14 May 1994.

104“FICCI Chief Against Trade Bodies Merger," The Financial Express, 2 July 1990.
} 
meetings with the prime minister, government leaders, and foreign dignitaries. ${ }^{105}$ This body failed to take shape at that time as leading industrialists in FICCI felt that such a body would affect its functioning. ${ }^{106}$ Again in 1995, another joint body was mooted to coordinate strategy vis-à-vis external actors. The initiative to have a unified front was first mooted by L.M. Thapar and Mr. S.K. Birla in early 1995 [members of FICCI]. CII president, Mr. Rajive Kaul, also favored the idea of working together both with FICCI and Assocham on issues relating to external relations. This effort followed a realization by top industrialists that, "they are wasting their time, energy and money in separately hosting visiting foreign businessmen under the aegis of Assocham, CII or FICCI when the issues for discussion are common. So why not constitute a coordinated body which gives equal representation to the three apex chambers."107 Yet again, this body was never instituted and the three chambers today continue to invite foreign dignitaries separately. ${ }^{108}$ In 1993 attempts to form an India International Business Council (IIBC) by R.P Goenka, with the support from the foreign ministry of the Government of India, and with inclusion of all the three chambers came to nothing as it increased infighting rather than any collective or cooperative action. $^{109}$ Again in 2000, there was some effort to present a joint set of recommendations on the annual budget but the three chambers could not agree to do so. FICCI proposed the joint proposal idea but CII and Assocham preferred to go it alone and give their separate suggestions to the Finance Minister. ${ }^{110}$ Thus, competitive politics between the three chambers has continued to be a pervasive feature of the interest representation map in India. On one hand, the lack of business unity affects the nature of business coherence and the strength with which the business community can negotiate with the government. On the other hand, this competition stimulates adoption of developmental features by both CII and FICCI.

\section{Institutional Reasons for the Persistence of Fragmentation among Business Associations}

State leaders also have strong incentives to encourage the ongoing fragmentation among the main business bodies. In 2001, the BJP's leadership

\footnotetext{
105“FICCI, ASSOCHAM, CII Plan Joint Panel," Indian Express, 27 July 1992.

106“Apex Body of Chambers Hanging Fire," The Telegraph, 28 September 1992; "FICCI Stymies Apex Panel of Chambers," Business Standard, 28 September 1992.

${ }^{107}$ Koteshwar P. Dobhal, "Move to Unite Apex Trade Bodies Gets a New Thrust," The Observer (ND), 22 August 1995.

${ }^{108}$ See, "Divided Chambers," The Business and Political Observer, 20 January 1997.

109"New Body Leaves Chambers Unhappy," Times of India, 10 October 1993.

110“"Apex Chambers Divided on Growth Rate Proposals to FM: FICCI for Joint statement, CII and ASSOCHAM Want to Go Separately," Business Standard, 10 October 2000. Also see, "Unholy Chamber Wars over JBC: Assocham versus FICCI” M.P Chronicle (Bhopal), 4 August 2000.
} 
sought to "discipline" the CII, which it thought had become too powerful. The prime minister refused to attend a CII function and began to sponsor and encourage its rival, the FICCI. ${ }^{111}$ This divide and rule strategy continued when FICCI was given the opportunity to sponsor a prestigious Indian Diaspora event in 2003 and 2004 where the prime minister addressed the delegates. This selective access to some business associations further enhanced the competitive fervor among the two business associations and the ability of the state to shape the political power of business groups. Thus, state actors, at key moments, gave or denied access to business associations.

India's fragmented cabinet structure (coalition governments in the 1990s) and its ongoing regionalization also prevented the consolidation of business associations; many associations had access to different types and levels of state institutions. In the mid 1980s and early 1990s, CII was linked to the Ministry of Finance and the Prime Minister's Office (PMO) and cultivated its connections with the civil service. FICCI had strong links with the Congress Party and other ministries such as the Ministry of Industry and Commerce. As regional forces became more institutionalized, CII and FICCI accelerated their state-level programs and offices; multiple institutional access in India's "divided leviathan",112 facilitated these business associations but also limited their consolidation and development into an encompassing nation-wide association. Simultaneously, as India's political system became more "decentered," 113 business associations diversified their strategies to target many different parties (especially regional parties) and coalition forces. For example, CII began to interact with numerous opposition parties when a minority government of PV Narasimha Rao needed support from opposition parties for the survival of its economic reform program and coalition partners of the BJP government from 1996 onwards. ${ }^{114}$ The need to access and build interactions with multiple power centers within the Indian state prevented the transformation of these business associations into a coherent nationwide association; thus the nature of state power-its divided character-shaped the continuing fragmentation within the business community.

\section{Conclusion}

Conventional scholarship views business associations as functional responses to crucial market and state failures or as rent-seeking organizations

\footnotetext{
${ }^{111}$ In 2002 after some criticism of the Gujarat riots at a CII organized meting, Vajpayee refused an invitation to address CII's sponsored World Economic Form meeting, a norm that had been followed by many previous PMs. Other ministers - Jashwant Singh (Foreign Minister at that time) and Arun Jatiley (Commerce Minister at that time) - also refused to address the meetings.

${ }^{112}$ Sinha (2005).

${ }^{113}$ Echeverri-Gent (2002).

${ }^{114}$ India was run by a minority government in 1991 and coalition governments in 1996, 1998, 1999 , and 2004.
} 
seeking private benefits. Both these views are non-political; one views business organizations as adequate functional responses, while the other fails to theorize the role of the state and political institutions. I propose an alternative framework that looks at the interaction between powerful business actors, the pre-existing institutional context, and the nature of state power. In my argument, business associations are political organizations seeking power and influence. Their developmental role in a society is a byproduct of their power-seeking activities. In this respect they are similar to other political organizations in society. In seeking power, they respond and adapt to the existing distribution of power, the sinews of state power and potential of threat from other associations. Thus, in dirigiste contexts, nature and distribution of state power and business competition will shape the activities, tactics, and strategies adopted by business associations.

If this is true, then, how may we understand the rise and consolidation of power by new business associations, like CII, and the transformation of existing business association, like FICCI? Giving analytical importance to the nature of state power in a system will tell us that new associations will arise only when openings in the national political opportunity structure allow access and new opportunities to such emergent organizations. Certain state actors may catalyze their emergence and development. These insights are derived from Ben Ross Schneider's argument about the role of specific actions and incentives of state actors (rather than macro state or political variables). I combine his stress on the role on state actors and their incentives with the idea from the social movement literature that changes in political opportunities and constraints within the state may provide the openings for business organization or disorganization. When such openings exist, reformers within the state may be emboldened to encourage the organization of business. Reformist state allies must facilitate the entry of outsider organizations and allow them access. Further, and most crucially, the entry of new associations and organizations is conditioned not only by the opportunities and openings, but also threats and challenges within the dominant power hierarchy. ${ }^{115}$ Thus, the nature and structure of the domestic business environment may be a crucial element in the domestic opportunity structure. In established democracies, where interest groups have long-standing activities and power, openings within the business system-weakness of existing associations, and competition with other peak associations (a competitive versus a monopolistic business environment)—will shape the rise of new developmental associations. Such competition with rival associations may catalyze new and existing associations to acquire developmental features.

This analysis of India presents a few interesting and puzzling features to our comparative understanding of business development. The 1990s saw the transformation of a weak and fragmented business system into a developmental

\footnotetext{
${ }^{115}$ In a recent re-formulation, McAdam, Tilly, and Tarrow (2001, 45-46) emphasize the joint impact of opportunities and threats.
} 
yet fragmented business system. In contrast to the general presumption that competition between associations may weaken both, competition, in fact, contributed to the transformation of weaker associations into stronger ones. ${ }^{116}$ Even more interestingly, despite an enhancement of business power (with globalization), the state continues to shape the nature and extent of business access to the political system. State actors also facilitate the rise of better organizations when this suits their public policy purposes (reform program) and aids in power struggles within a conservative state.

These conclusions emerge from a historically oriented framework that pays careful attention to both the macro-political environment and the mesoinstitutional business environment faced by capital and collective organizations. Employing concepts from the social movement literature as well as historical institutional arguments yields a better understanding of the political underpinnings of collective action. This framework is more attuned to the political and power dynamics that give shape to interest representation in globalizing India than its alternatives. Thus, an analysis of developmental collective action in India warns us against taking an overly functional account of business associations. Associations and organizations not only serve functional needs of its members and the state but also seek political power and influence; they, therefore, must be understood with the help of political and contextual variables.

This empirical analysis points toward the theoretical importance of key concepts used in this article: the political opportunity structure, and impact of historical institutions. Reformist openings within the state represented by Rajiv Gandhi (India's prime minister from 1985-1989) and Manmohan Singh (India's finance minister in the early 1990s) point toward the need to analyze the role of specific state actors, and the structure of opportunities and threats presented by various political institutions in other contexts. Equally important, the historical matrix of institutions in the form of federal structures and the legacy of informal and dirigiste state traditions, point to the power of historical institutionlist arguments. This analysis of continuity and transformation in business politics shows the path-dependent character of institutions, revealing how apparently nonfunctional institutions persist. ${ }^{117}$ Yet pre-existing institutional patterns are not merely sources for inefficiency; they also provide pre-conditions for innovation. Given the historical pattern of business-state nexus-its rent-seeking and particularistic character-competition among associations stimulated the adoption of developmental features by many associations as each sought to distinguish themselves from the weak organizations of the recent past.

\footnotetext{
${ }^{116}$ This is in contrast to the conventional view that weaker organizations and fragmentation coexist. In Argentina and Brazil for example, weakness and fragmentation of business organization go together.

${ }^{117}$ See Steinmo, Thelen and Longstreth (1992); Pierson (2004); and Thelen (2004).
} 
We therefore need an independent theory of historical genesis and transformation of developmental associations. Such a theory must attend explicitly to political variables, conceptualized as set of opportunities and threats and to changing openings within them; the rise of developmentally oriented associations, a somewhat rare occurrence, must struggle against the alignment of political forces in the larger system. I identified three important elements of the larger political system which play a major role in giving birth to developmental associations: the role of the state leadership; the structure of the state (federalism), and the competitive configuration of the business system. The isolation of these variables for India has led me to outline the story of the transformation of business collective action in India. Threats from competitive organizations and the extent of organizational weakness in the business system may facilitate the rise and consolidation of developmental-oriented organizations. A competitive business system-marked by a large number of associations, movement of members among the associations, competitive effort to seek the government's attention-may facilitate the transformation of existing associations into developmental ones. Second, the role of the state in facilitating the emergence and transformation of developmentally oriented associations may prove to be more crucial than prevailing theories or predictions about receding state power predict. Despite globalization, states continue to shape the nature and power of business collective action.

\section{Colophon}

Author: Aseema Sinha, Assistant Professor, University of Wisconsin-Madison and Woodrow Wilson Fellow

E-mail: asinha@polisci.wisc.edu

Mailing Address: 212 North Hall, Department of Political Science, University of Wisconsin-Madison, Madison, WI 53706.

Acknowledgement:

This paper relies on fieldwork conducted in India in 1997-1998, January 2002, and July 2003-July 2004. I thank an AIIS grant, which made the field research possible. A Woodrow Wilson Center fellowship provided a congenial context at the writing stage. This paper was first presented at the Annual meeting of the Annual Political Science Meeting in 2003. I thank Ken Shalden, who served as the discussant at APSA 2003. I am grateful to the two anonymous reviewers' and the editor of Business and Politics for very useful comments. I also thank John Echeverri-Gent, Shomikho Raha, Alasdair Bowie, and Anindya Saha for comments. I owe thanks to Jorgen Pedersen for sending me a copy of the 1992 CII directory. Adam Kroetz, Amrita Sharma, and Jennifer Brick provided 
valuable research assistance. I thank all of the interviewees who spoke with me with frankness and openness; I am unable to acknowledge their contributions directly given the sensitive nature of the views expressed. 


\section{References}

\section{Primary Sources:}

\section{Newspapers:}

The Hindu: 1990-2004

Business Line: 1990-2004

The Economic Times: 1990-2004

The Financial Express: 1990-2004

Business Standard: 1990-2004

Indian Express: 1990-2004

Other Newspapers Consulted:

The Patriot

The Telegraph

Business and Political Observer

The Times of India

The Statesman

The Independent

\section{Documents}

CII (Confederation of Indian Industry). Annual Report: Various Years.

CII, Membership Directory, 1993, and 2003.

CII. 2003.The Electricity Bill 2003; A Brief Note on CII's Views and Suggestions.' June.

CII. 2003. Communiqué. Special Issue. June 
CII. 2003. "India and USA." Pamphlet.

CII. Press Releases

http://www.ciionline.org/

\section{FICCI Documents}

FICCI, Annual Report, Various Years.

FICCI, Press Releases.

http://www.ficci.com/ficci/index.htm

\section{Secondary Sources}

Alavi, Hamza. 1982. 'State and Class Under Peripheral Capitalism.' In Introduction to the Sociology of Developing Societies, edited by Hamza Alavi and Teodor Shanin. London: Macmillan.

Amsden, Alice. 1989. Asia's Next Giant: South Korea and Late Industrialization. New York: Oxford University Press.

Bardhan, Pranab. 1984 [1998]. The Political Economy of Development in India, Expanded Edition. Delhi: Oxford University Press.

Cerny, Philip G. 1995. 'Globalization and the Changing Logic of Collective Action,' International Organization 49 (4): 595-625.

Chibber, Vivek. 2003. Locked in Place: State-Building and Late Industrialization in India. Princeton, NJ: Princeton University Press.

Doner, Richard and Schneider Ben. 2000. 'Business Associations and Economic Development Why Some Associations Contribute More than Others.' Business and Politics 2(3): 261-88.

Echeverri-Gent, John. 2002. 'Politics in India's Decentered Polity.' In India Briefing: Quickening the Pace of Change, edited by Alyssa Ayres and Philip Oldenburg. Armonk, New York: M.E. Sharpe. 
Evans, Peter. 1995. Embedded Autonomy. Princeton, NJ: Princeton University Press.

Fields, Karl. 1997. 'Strong States and Business Organization in Korea and Taiwan.' In Business and State in Developing Countries, edited by Sylvia Maxfield and Ben Ross Schneider. Ithaca: Cornell University Press.

Goldsmith. Arthur A. 2002. 'Business Associations and Better Governance in Africa.' Public Administration and Development 22: 39-49.

Gordon, Colin. 1998. 'Why No Corporatism in the United States? Business Disorganization and its Consequences.' Business and Economic History Vol. 27 (1): 29-46.

Hardin, Russell. 1982. Collective Action. Baltimore: Johns Hopkins University Press.

Harriss, John 1987. 'The State in Retreat: Why Has India Experienced Such HalfHearted Liberalization in the 1980s?' IDS Bulletin 18(4): 29-36

Hart, David M. 2004. "Business" Is Not an Interest Group: On the Study of Companies in American National Politics.' Annual Review of Political Science 7:47-69.

Herring, Ronald. 1999. 'Embedded Particularism: India's Failed Developmental State.' In The Developmental State, edited by Meredith Woo-Cummings. Ithaca: Cornell University Press.

Jenkins, Rob. 1999. Democratic Politics and Economic Reform in India. Cambridge: Cambridge University Press.

Johnson, Chalmers. 1982. MITI and the Japanese Miracle: The Growth of Industrial Policy, 1925-1975. Stanford, CA: Stanford University Press.

Kang, David C. 2002. Crony Capitalism: Corruption and Development in South Korea and the Philippines. New York: Cambridge University Press.

Kim, Eui-Young. 1993. 'The Developmental State and the Politics of Business Interest Associations: The Case of the Textile Industry in South Korea,' Pacific Focus 8(2): 31-60. 
Kingstone, Peter R. 1999. Crafting Coalitions for Reform: Business Preferences, Political Institutions, and Neoliberal Reform in Brazil. University Park, PA: Pennsylvania State University Press.

Kochanek, Stanley 1974. Business and Politics in India. Berkeley: University of California Press.

— 1985. 'The Politics of Regulation: Rajiv's New Mantras.' Journal of Commonwealth and Comparative Politics 23(3): 189-211.

. 1986. 'Regulation and Liberalization Theology in India.' Asian Survey 26(12): 1284-1308.

- 1987. 'Briefcase Politics in India: The Congress Party and the Business Elite,' Asian Survey 27(12): 1278-1301.

—. 1995-1996. 'The Transformation of Interest Politics in India.' Pacific Affairs 68(4): 529-551.

- 1996. 'Liberalization and Business Lobbying in India,' Journal of Commonwealth and Comparative Politics 34, no. 3: 155-73.

Kohli, Atul. 1989. 'The Politics of Economic Liberalization in India.' World Development 17(3): 305-328.

Krueger, Anne O. 1974. 'The Political Economy of the Rent Seeking Society.' American Economic Review 64(3): 291-303.

Lehmbruch, Gerhard and P. C. Schmitter, editors. 1982. Patterns of Corporatist Policy-Making. London: Sage.

Lehne, R. 2001. Government and Business: American Political Economy in Comparative Perspective. New York, NY: Chatham House Publishers.

Martin, C. J. 2000. Stuck in Neutral: Business and the Politics of Human Capital Investment Policy. Princeton, NJ: Princeton University Press.

Maxfield, Sylvia and Ben Ross Schneider, editors. 1997. Business and State in Developing Countries. Ithaca: Cornell University Press.

McAdam, Doug, Sidney Tarrow, and Charles Tilly. 2001. Dynamics of Contention. New York: Cambridge University Press. 
Nayar, Baldev Raj. 1998. 'Business and India's Economic Policy Reforms.' Economic and Political Weekly 33(38): 2453-2468. . 2001. Globalization and Nationalism: the Changing Balance in India's Economic Policy, 1950-2000. New Delhi: Sage Publications.

Noble, Gregory W. 1998. Collective Action in East Asia: How Ruling Parties Shape Industrial Policy. Ithaca, NY: Cornell University Press.

Offe, Claus and Helmut Wiesenthal. 1985. 'Two Logics of Collective Action.' In Disorganized Capitalism: Contemporary Transformations of Work and Politics, edited by John Keane and Claus Offe. Cambridge, MA.: MIT Press.

Olson, Mancur. The Logic of Collective Action; Public Goods and the Theory of Groups. Cambridge, MA: Harvard University Press, 1965.

Oliver, Pamela. 1993. 'Formal Models of Collective Action.' Annual Review of Sociology. 19: 271-300.

Payne, Leigh A. 1994. Brazilian Industrialists and Democratic Change. Baltimore: Johns Hopkins University Press.

Pedersen, Jorgen Dige. 2000. 'Explaining Economic Liberalization in India: State and Society Perspectives.' World Development 28(2): 265-82.

Perez-Aleman, Paola. 2003. 'A Learning-Centered View of Business Associations: Building Business--Government Relations for Development.' Business and Politics 5(2): 193-213.

Pierson, Paul. 2004. Politics in Time: History, Institutions, and Social Analysis. New Jersey: Princeton University Press.

Rudolph, Lloyd I. and Susanne H. Rudolph. 1987. In Pursuit of Lakshmi: The Political Economy of the Indian State. Chicago: The University of Chicago Press.

Rudolph, Lloyd I. and Susanne Hoeber Rudolph, 2001, "Iconization of Chandrababu: Sharing Sovereignty in India's Federal Market Economy," Economic and Political Weekly, May 5, 2001: 1546-1560.

Saez, Lawrence. 2002. Federalism Without a Center: The Impact of Political and Economic Reform on India's Federal System. New Delhi: Sage. 
Schmitter, Philippe C. and Gerhard Lehmbruch, editors. 1979. Trends toward Corporatist Intermediation. London: Sage.

Schmitter, Philippe C. 1994. 'Organized Interests and Democratic Consolidation in Southern Europe.' In The Politics of Democratic Consolidation, edited by Richard Gunther, Nikiforos Diamandouros and Hans Jurgen Puhle. Baltimore: Johns Hopkins Press.

Schneider, Ben Ross. 1998. 'Elusive Synergy: Business-Government Relations and Development.' Comparative Politics 31(1): 101-122.

Schneider, Ben Ross. 2004. Business Politics and the State in Twentieth-Century Latin America. Cambridge: Cambridge University Press.

Shastri, Vanita. 1997. 'The Politics of Economic Liberalization in India.' Contemporary South Asia 6(1): 27-56.

Sinha, Aseema. 2005. The Regional Roots of Developmental Politics in India: A Leviathan Divided. Indiana: Indiana University Press.

Smith, M. A. 2000. American Business and Political Power: Public Opinion, Elections, and Democracy. Chicago: The University of Chicago Press.

Steinmo, Sven, Kathleen Thelen, and Frank Longstreth, editors, 1992. Structuring Politics: Historical Institutionalism in Comparative Analysis. Cambridge: Cambridge University Press.

Swenson, Peter A. 2002. Capitalists against Markets: the Making of Labor Markets and Welfare States in the United States and Sweden. Oxford: Oxford University Press.

Tarrow, Sidney. 1998. Power in Movement: Social Movements and Contentious Politics, $2^{\text {nd }}$ Edition. Cambridge: Cambridge University Press.

Thelen, Kathleen. 2002. 'The Political Economy of Business and Labor in the Developed Democracies.' Political Science: the State of The Discipline, edited by Helen Milner and Katznelson. New York: Norton and Company.

Thelen, Kathleen. 2004. How Institutions Evolve: The Political Economy of Skills in Germany, Britain, the United States, and Japan. Cambridge: Cambridge University Press. 
Truman, David Bicknell. 1971. The Governmental Process, Political Interests and Public Opinion. New York: Knopf.

Varshney, Ashutosh. 1999. 'Mass Politics or Elite Politics?: India's Economic Reforms in Comparative Perspective.' In India in the Era of Economic Reform, edited by Jeffrey D. Sachs, Ashutosh Varshney, and Nirupam Bajpai. New Delhi: Oxford University Press.

Vogel, David. 1989. Fluctuating Fortunes: the Political Power of Business in America. New York: Basic Books.

Wilson, Graham K. 2003. Business and Politics: A Comparative Introduction. 3rd Ed. New York: Chatham House Publishers. 